\title{
The state policy in the field of school education in the Soviet Russia in 1917-1923
}

\begin{abstract}
This article reviews Bolshevik policy in the field of school education in the early years of Soviet power. The author draws attention to the ideological and political differences between the party and most of the teachers, which intensified after the Bolsheviks seized power. The atmosphere of mutual distrust negatively affected the social policies concerning teachers at the local level. The terrible financial situation of the teachers led to a critical shortage of staff, a decrease in the overall competence of school employees, lack of motivation and capacity to effectively implement school reform. At the same time, the authorities significantly increased the requirements for teachers. Therefore, the Bolsheviks' concept of the "labour school" was implemented with considerable distortions, causing a general decline in the quality of school education. Summing up the experience of school policy in the first years of the Soviet power, the Bolsheviks understood the need to review their attitude to people's teachers and in particular to the remuneration of their labour.
\end{abstract}

Keywords: soviet power, Bolsheviks, teachers, professional organisations, school, school reform, labour school.

\section{Introduction}

The period from 1917 to 1923 can undoubtedly be called the most difficult in the history of Russian education. Civil war, famine and devastation were major, but not the only causes of the crisis in the field of public education. The party's attitude to educational content, to methods of teaching and the educational process, as well as their social policy concerning teachers had a decisive influence on the situation in this field. The government's policy was rather ambiguous. In many respects, it was determined by the personal attitude of influential party members, and was implemented significantly differently in the centre of the country and out in the provinces. The comprehensive study of 
this policy is a complex task that can greatly expand our understanding of the processes which were taking place in Soviet society during this period.

Consequently, the problem with the party's educational policy in the early years of Soviet power is of considerable interest for researchers. It is best covered in the works of Larry E. Holmes ${ }^{1}$ and Sheila Fitzpatrick. ${ }^{2}$ While in Sheila Fitzpatrick's book, the ideas and activities of influential Bolsheviks (A. Lunacharsky, N. Krupskaya) are examined in great detail, Larry E. Holmes pays more attention to the discrepancy between the declared government policy and its practical implementation.

In recent years, a great number of research publications appeared in the post-Soviet region. Their authors, using a broad source base, reveal the problem of financial support of the teachers ${ }^{3}$ and the specific relationship of teachers and the Soviet authorities at the local level. ${ }^{4}$

The work with periodicals from 1917 to the first half of the 1920s plays a major role in this research. In the educational magazines of the period, it is possible to find not only discussions about the educational methods (their main content), but also individual evaluative judgments about government policy, about educational resources and the financial support of schools which had not yet been subjected to strict censorship. The study of these sources allowed the author of this article to create a comprehensive view of the condition of public education and the main problems in this sector, which have been outlined below.

\section{Political and ideological differences}

The relationship between the Bolshevik Party and Russian teachers was not the best, even before the October revolution. As early as at the beginning of 1914, summarising the results of the congress on public education, Nadezhda Krupskaya noted that "the class point of view is hostile to most teachers". This is quite predictable, because most often the teachers were those to whom the Bolsheviks, in their propaganda, assigned the role of class enemies - noblemen, industrialists, merchants, officials, clergy or well-to-do peasants. ${ }^{6}$

\footnotetext{
${ }^{1}$ Holmes L.E., The Kremlin and the Schoolhouse: Reforming Education in Soviet Russia, 1917-1931, Bloomington 1991.

2 Fitzpatrick S., The Commissariat of Enlightenment: Soviet Organization of Education and the Arts under Lunacharsky, October 1917-1921, Cambridge 2002.

${ }^{3}$ Sergeyev I., Financial Situation of 'People's Teacher' in Soviet Russia in 1917-1921 [in Russian], "Visnyk Kharkivs'koho natsional'noho universytetu im. V.N. Karazina”, 2007, no. 39, pp. 185-97.

${ }^{4}$ Mankivska T., The Policy of Soviet Power Concerning Teachers in 1917-1921 (based on data from Slobozhanskyi Region) [in Ukrainian], “Zbirnyk naukovykh prats' Kharkivs'koho natsional'noho pedahohichnoho universytetu imeni H. S. Skovorody”, 2012, no. 44, pp. 134-8.

${ }^{5}$ Krupskaya N., Pedagogical Works [in Russian], Moscow 1957, vol. 1, p. 234.

${ }^{6}$ Bushchyk L., Essay of School History Education Development in the USSR [in Russian], Moscow 1961, p. 89 .
} 
The teachers, especially in large cities, were not indifferent to politics. However, virtually all educational literature in the country, as well as teachers' professional organisations, were mainly under the supervision of cadets, and partially by Mensheviks and Socialist-Revolutionaries (S. Rs.). The attitude of teachers to the Bolsheviks overall was extremely negative, as, indeed, were the intellectual classes as a whole.

The seizure of power by the Bolsheviks led to a complete collapse in the educational sector. The Ministry of National Education continued its work for more than a week, completely ignoring the new government. Subsequently, all the officials resigned from the Ministry. The Committee on Public Education, as well as the Ministry, did not respond to the proposal of cooperation made by Anatoly Lunacharsky, the newly appointed Commissar of Education, and during their personal meeting, its Head refused to shake hands with Lunacharsky, as if he were a public enemy. ${ }^{7}$

Immediately after the October revolution, the management of the All-Russian Teachers' Union (the sole united trade union of school employees) organised numerous protests of teachers and parents against Soviet power, accompanied by strongly worded anti-Bolshevik publications in the press. ${ }^{8}$ In December 1917, the Union organised the largest strike of teachers, which lasted three months and affected Moscow, Petrograd, Ufa, Yekaterinburg, Astrakhan and other Russian cities. ${ }^{9}$

The most disastrous thing for the Bolsheviks was the situation in secondary schools. Their refusal to accept Soviet power was so widespread that those few teachers who dared to declare their support for the new government were subjected to various kinds of harassment. Moreover, the Bolsheviks' children experienced considerable pressure themselves. The problem acquired such magnitude that the Commissar of Education had to dedicate a speech to it, threatening to arrest those involved in such harassment. ${ }^{10}$

We learn about the helplessness of the government and its inability to influence the uncontrollable secondary schools from the official press. Thus, the Department of secondary schools of the State Commission for Education proposes to create "socialist grammar schools", where it plans to transfer from regular schools all children of socialists and teachers-socialists, - to create secondary schools of "socialist refugees fleeing from the realm of petty-bourgeois frenzy". ${ }^{11}$

Another means of self-preservation through self-isolation was the creation of the Union of Teacher-Internationalists, which was supposed to unite "all figures in the field of education and upbringing motivated by social revolution and destruction of the modern

\footnotetext{
${ }^{7}$ Lunacharsky A., Memories and Impressions [in Russian], Moscow 1968, p. 181.

8 Vitukhnovskij G., Fight for Teachers in the First Months of Soviet Power [in Russian], "Sovetskaia Pedagogika", 1956, no. 11: 72-73.

${ }^{9}$ Essays on the History of School and Pedagogical Thought of the USSR. (1917-1941), ed. Kuzin N., Kolmakova M., Ravkin Z. [in Russian], Moscow 1980, p. 180.

10 Department of Secondary Schools [in Russian], "Narodnoe prosveshchenie", 1918, no. 1-2, p. 13.

11 Ibidem, p. 18.
} 
school system". ${ }^{12}$ Such a Union could not replace the All-Russian Teachers' Union because it was not a trade union organisation, and because it was a lot more limited in its influence due to its political and ideological direction. Later, the Bolsheviks themselves recognised establishing of the Union of Teacher-Internationalists as one of the incorrect attempt to create "red separatist unions". ${ }^{13}$

However, if in Russian cities the teachers were a large and organised force, able to take a hard-line stand against Soviet power, in the provinces it was quite a different picture. Few in numbers, teachers were left face-to-face with local authorities, completely dependent on them. The attitude to teachers in the provinces differed significantly from the relatively soft approach used by Anatoly Lunacharsky and Vladimir Lenin.

In the country's regions, especially in rural areas, the Bolsheviks did not stand in awe of teachers' honourable educational mission. Teacher's political opinions and class standing came first, and they often were declared bourgeois and counter-revolutionaries. We can find out about such attitudes to teachers mostly from pedagogical literature published outside the territory controlled by the Bolsheviks. ${ }^{14}$

However, we can also find evidence of such a policy in the periodicals published in the Soviet territory, albeit in a milder form. One article in particular, published in the professional magazine "Pedagogicheskaia Mysl", points out that "the labour school, which is often, very often (see newspapers and chronicles of educational magazines) imposed by "local powers" with such courage and such mockery of the teacher, this school is not a labour school, but a destruction and ruining of both the school and the child's mind...". Further, the editors note that this phenomenon "is not only frequent, but, perhaps, common at the local level". ${ }^{15}$

The difference in attitude towards the teachers between central and local authorities can also be felt, when, in the same issue, defending teachers from the image created by Bolshevik theorist Pavel Blonsky, the editorial board appeals to Anatoly Lunacharsky, a "truly People's" Commissar for Education, who " has repeatedly expressed his deep respect for the work of people's teachers". ${ }^{16}$

However, we should not overestimate the so-called "soft line" of People's Commissariat for Education. In part, it did not go beyond passionate speeches of Anatoly Lunacharsky; and party leaders mostly addressed teachers in a commanding tone (for example-Lenin's speech in June 1918 at the All-Russian Congress of Teacher-Internationalists ${ }^{17}$ ). The party leadership did not intervene in relationships between local governments and p 49.

${ }^{12}$ Charter of Union of Teacher-Internationalists [in Russian], "Narodnoe prosveshchenie", 1918, no. 1-2,

${ }_{13}$ Kozelev B., Our Greetings to the Teachers and Education Employees of All Countries - the Delegates of the 1st World Congress of Trade Unions [in Russian], "Rabotnik prosveshcheniia", 1921, no. 7, p. 13.

${ }^{14}$ Alferov S., The Needs of the Don People's School [in Russian], "Pedagogicheskaia mysl. The journal issued by the Department of People's Enlightenment of the Don Great Army", 1918, no. 2, p 77.

${ }_{15}$ Around School Being Built [in Russian], "Pedagogicheskaia mysl”, 1919, no. 1-3, p. 128.

${ }^{16}$ Ibidem, p. 130.

${ }^{17}$ Lenin V., Complete Collection of Works: in 55 v. [in Russian], Moscow 1969, vol. 36, p. 420-421. 
teachers in the provinces, because they were just one of the manifestations of the hostility that spread through the society of the former Russian Empire during the Civil War. During the war, teachers were often among the fighters against Bolshevism, and this fact could cause reprisals against them including execution. ${ }^{18}$ This also had a very negative impact on schools' human resourcing. Thus, the message of the Bulletin of the Upper Don District Department of Education is quite typical; it states that in 1919, when the region came under the power of the Bolsheviks, there were only 11 teachers remaining in 179 schools, the rest went with the White Guard. ${ }^{19}$

\section{Teacher's state of affairs}

Mutual distrust between teachers and the Soviet government during the period of catastrophic shortage of money and food supplies was an additional factor that led to the complete impoverishment of teachers.

We can learn from one of the speeches of Mikhail Pokrovsky, Deputy Commissar of Education, how local authorities carried out the distribution of funds in practice:

"Regional governments, which were obtaining loans at the time, when the loan's real value was already three times lower than on the date of the estimate, were rushing to replenish the naturally resulting budget deficit and in order to do so, were first of all grabbing "educational" funds. Consequently, - and this happened in the majority of cases - the teachers received absolutely nothing or received January's salary as late as in December: however, during this period the value of money fell 10-fold. Regional governments have correctly reasoned that the police would run away, if not paid, the hospitals would shut down, but the school would "somehow" survive". ${ }^{20}$ Evidence of such misuse of "educational" funds can also be found in the periodical publications of that time. ${ }^{21}$

However, most often, we read about the consequences of such an attitude towards the public teacher in the press. The pedagogical publications of 1917-1923 were filled with news about the plight of the ordinary teacher, especially when they had received evidence from places where there were long delays with payment of wages and shortages of food rations. ${ }^{22}$

During the provincial conference of the Teachers Union held on January 17 in Novgorod, a representative of one of the districts said that if those who teach were not satisfied with the rations, then there would be no work carried out with them and all educational

\footnotetext{
18 Solodub P., Revolution and People's Teacher [in Ukrainian], "Radianska osvita”, 1925, no. 1, p. 10-11.

19 Radchenko A., Training of School Employees at the Local Level [in Russian], "Na putiakh k novoi shkole", 1922, no. 2, p 94-5.

${ }^{20}$ Pokrovsky M., Selected Works [in Russian], Moscow 1967, vol. 4, p. 501.

21 To all Education Workers [in Russian], "Put Prosveshcheniia", 1922, no. 2, pp. 371-373.

22 At the Local Level [in Russian], "Rabotnik prosveshcheniia", 1921, no. 4-5, p. 41.
} 
establishments would be shut down. In her speech, she made such harsh statements that the Chairman of the meeting was forced to stop her twice during her speech. ${ }^{23}$

Poor wages, political, ideological and administrative pressure and the loss of status of the teaching profession made it highly unpopular among the educated part of the population.

In a report from the city of Yaroslavl, we find a quote from the minutes of the Provincial Committee: "The School is being destroyed due to the lack of school staff. A massive desire to leave the teaching profession is in evidence and it is necessary to direct all efforts to retaining those who are leaving the workplace". ${ }^{24}$

However, it was impossible to stop the outflow of specialists from the educational sector under the existing conditions. Having chosen the profession of teacher, you were exposed to constant criticism both from official authorities, unsatisfied with school reforms, and also often from a local population opposed to the anti-religious rhetoric of schools at that time. In addition, being a teacher meant poverty for the person who chose it, because education was funded according to the principle of only giving it the leftovers and the authorities considered it unacceptable to involve the local population in financing schools through tuition fees.

Teacher resignations from teaching became so widespread that the Council of People's Commissars had to resort to the most drastic measures. The decree "On the elimination of illiteracy among the Population of the Russian Socialist Federative Republic" was issued on December 26, 1919, according to which all literate people could be recruited by local authorities to perform labour service in the form of academic work. Failure to comply with this obligation could lead to criminal liability. ${ }^{25}$ In the spring of 1921 the decree "On the return to work according to their qualifications of teachers and culture specialists" was passed, under which teachers were obliged to return to work in educational institutions. ${ }^{26}$

According to contemporary estimates, the demand for teachers in 1921, only in Moscow and the Moscow Region, was ten thousand. In some areas of the RSFSR (the Russian Soviet Federative Socialist Republic) the number of teachers reached only $25-30 \%$ of the quantity necessary for the functioning of schools. ${ }^{27}$

A characteristic of that time was the reluctance of young people to enter pedagogical educational institutions and to engage in teaching work. The teachers at the Mykhailivsk pedagogical technical school indicated "avoidance of pedagogical work by students, to which they are not attracted, although they realise the great importance of this work and in theory, value it". The teachers also add: "The fact that from the very beginning we

23 Ibidem, p. 40.

24 Ibidem, p. 38.

${ }^{25}$ Decrees of Soviet Power [in Russian], Moscow 1974, vol. 7, p. 50-51.

${ }^{26}$ Higher School of the Ukrainian SSR for 50 years. In two parts, ed. Pipov V. [in Ukrainian], Kyiv 1967, vol. 1, p. 105 .

27 Kalashnikov A., On the Preparation of Educators [in Russian], "Rabotnik prosveshcheniia", 1921, no. 7 , p. 19 . 
immerse our students in pedagogical work, however, cannot save the school from the fact that the best-trained forces will avoid it, heading for the best-paid services or higher educational institutions". ${ }^{28}$

It stands to reason, this state of affairs affected not only the number of teachers, but their overall level of competence. Lack of staff was covered mainly by young people who had just finished secondary schooling and had received "in general opinion, a very modest training" or by completely unqualified individuals. ${ }^{29}$ As of 1922 , about $75 \%$ of teachers had only a secondary education and $13 \%$ - even lower. $40 \%$ of teachers had no more than 5 years' experience.

In an attempt to at least partially rectify the situation of mass-scale incompetence of teachers, the Bolsheviks directed significant efforts and resources to the organisation of numerous short-term courses. However, such courses could not replace a comprehensive education and did not produce the desired effect, as the information obtained required consolidation through further self-education and practice. It was impossible to expect uneducated and hungry teachers to carry out any self-development to improve their skills.

One of the lecturers shared his experience of conducting such courses for teachers:

"There are no books, but there is interest and thirst for knowledge; they go to lectures and are eager to take the courses where they do not need to think about the next meal, where it is warm, where there are so many new experiences. A month passed - and again a gap, where nothing has been read for 6 months (there are questions in a questionnaire about what was read, if anything, during the last 6 months). Neither newspapers, nor magazines, nor pamphlets, nor books. Nothing...

"It is absolutely clear," the author writes, "that in the next decade we will not have the teacher we need. We will have to work with a teacher who does not have sufficient knowledge, and does not have the ability to use it, who does not even know how work, how to teach..." 30

Thus, after five years of Soviet power, in 1923, according to the professional literature, the main problems of the schools were still the complete incompetence of teaching staff and chaos in understanding what a "labour" school is. ${ }^{31}$

\section{The results of the reform}

At the same time, the Bolshevik theoreticians of school reforms assigned this impoverished, uneducated and inexperienced average teacher the main role in creating a new school, expecting incredible dedication and creative methodological work from him at

\footnotetext{
${ }^{28}$ Review of the Mykhailivsk Pedagogical Technical School of Krupskaya's Article [in Russian], "Na putiakh k novoi shkole", 1923, no. 7-8, p. 247.

29 Radchenko A., Training of School Employees at the Local Level, p. 94.

${ }^{30}$ Shulgin V., On the Question of Work with Teachers [in Russian], "Na putiakh k novoi shkole”, 1922, no. 2, p 35-36.

31 Tumim G., Thoughts on Labor School [in Russian], "Prosveshchenie”, 1923, no. 3, p. 133.
} 
such a level that was out of reach even for professionals from the old school. Why the demands for the teachers have increased so much and what, in fact, the new "labour" school meant we will analyse further in this article.

Almost immediately after seizing power, the Bolsheviks, with their inherent determination and radicalism, undertook a radical restructuring of the school. However, according to their logic, in order to give life to the new school, it was necessary to destroy the "bourgeois" school. In his speech at the first All-Russian Congress of Education Anatoly Lunacharsky said: "We could not think like the Provisional Government that we shall impose some changes to the district inspectors. We had to destroy everything; it was clear that the school has to be subjected to revolutionary breaking". 32

Indeed, in the first years of Soviet power the new school was built based on the rejection of almost all elements of the pre-revolutionary school. The subject-based education system, the use of textbooks, ${ }^{33}$ homework assignments, examinations, and even a point-based knowledge evaluation system, were all rejected. ${ }^{34}$ In one of her articles, N. Krupskaya acknowledged, "the first years of the revolution were spent on breaking the old systems rather than creating new ones". 35

This approach to schoolwork made experienced schoolteachers feel completely incapable of doing their job. Thus, in the article of one of the teachers loyal to the innovations of the authorities, we find her confession: "That love is the greatest organising and controlling power among children ... I managed to understand, through working with children, but, further ... I could not teach them what I do not know myself. I could only give them my knowledge, but it would not be beneficial either to me or to them". ${ }^{36}$

In regards to the old school teachers, the destruction of the old school system meant to them the complete destruction of school education as a whole. Virtually all knowledge the old teachers had was declared redundant and, in part, even harmful. Some teachers reacted sensitively to the ban on all elements of Christian morality (as well as the local population) considering it a blow to the moral and ethical education of the younger generation. The majority of old teachers were ready to accept some changes, were waiting for a new curriculum, clear instructions which would allow them to effectively organise their work, but no detailed curriculum or methodological literature was forthcoming.

Therefore, it is not surprising that in general teachers were hostile to the authorities' actions, observing "the destruction of the existing school and the hasty, fitful attempts to create a new one". ${ }^{37}$ In general, the position of the ordinary teacher during these years is

32 Lunacharsky A., About the Upbringing and Education [in Russian], Moscow 1976, p. 22.

${ }^{33}$ Bushchyk, Essay of School History Education, p. 109.

${ }^{34}$ Lunacharsky A., On the abolition of marks [in Russian], "Narodnoe prosveshchenie", 1918, no. 4-5, p. 26. p. 3.

${ }^{35}$ Krupskaya N., To the Questions of Programs [in Russian], "Na putiakh k novoi shkole", 1922, no. 2,

${ }^{36}$ From the Letter of School Instructor [in Russian], "Na putiakh k novoi shkole", 1922, no. 2, p 78-79.

${ }^{37}$ Kapterov P., L. N. Tolstoy and the modern school conversion [in Russian], "Pedagogicheskaia mysl", 1919, no. 1, p. 2. 
best illustrated by the report of one of the District Departments of People's Education in Gomel Province, "it is impossible to work in the old way, the teachers cannot work in the new way, so what's left is to do nothing". ${ }^{38}$

The old school was supposed to be replaced by the so-called "labour school". The idea to combine education and moral upbringing with productive labour was inherited by K. Marx from an English philosopher and socialist Robert Owen, who considered this system to be the only way to create well-rounded individuals. ${ }^{39}$. It was included in the Manifesto of the Communist party ${ }^{40}$ and gained considerable popularity among Marxists.

Russian Bolsheviks not only strictly adhered to such an approach to education, but also for 20 years desperately attempted to implement it in Soviet schools. As far back as 1898, Lenin, in his article "Pearls of Russian populist impracticable projects," expressed his confidence in the fact that "neither studying and education without productive labour, nor productive labour without simultaneous training and education could be at the level required by modern technical and scientific knowledge." ${ }^{\prime 41}$

After the Bolsheviks' seizure of power and their declaration to form the so-called labour school, the topic of combining educational teaching process with production and public life became the most discussed topic in the pedagogical press. In 1918 the People's Commissariat of Education adopted the law on the United labour school, according to which productive labour had to become the basis of school life. ${ }^{42}$

The high level of interest in the introduction of labour methods into the education system was not just a tribute to theoretical thought of famous Utopians and socialists. In addition to the most obvious function - raising the level of labour productivity and the development of the country's economic system, according to the Bolsheviks' point of view - work at school had to perform another important function - moral upbringing.

Reform of the educational system was accompanied by the purposeful and decisive destruction of all the elements responsible for moral education during the time of the Russian Empire. One of the foremost Soviet teachers in 1923 spoke quite clearly on this subject: "We will insist that no authoritarian morality is introduced into the child's soul, no references to God, no religious sanctions, no references to any authorities". ${ }^{43}$ Educational institutions were combating everything connected with religion, first of all - the prohibition of teaching "the law of God".

History as a separate school subject was completely excluded from the Soviet school because the communists connected it with tsarist propaganda. Instead, the subject of "social science" was introduced. It focused on studying the modern age, using only spe-

${ }^{38}$ Bushchyk, Essay of School History Education, p. 163.

39 Marx K., Engels F., Works [in Russian], Moscow 1960, vol. 23, p. 495.

${ }^{40}$ Marx K., Engels F., Manifesto of the Communist party [in Russian], Moscow 1974), p. 47.

${ }^{41}$ Lenin V., Complete Collection of Works: in 55 v. [in Russian], Moscow 1971, vol. 2, p. 485.

42 Second degree of the Soviet labour school. Organisation. Contents. Methods [in Russian], Moscow 1929 , p. 52.

${ }^{43}$ Pinkevich A., About the necessity of Marxist pedagogy [in Russian], "Na putiakh k novoi shkole", 1923, no. 1(4), p 56. 
cific historic references to explain the origin of certain phenomena. The attitude of party's methodologists to this problem can be found in an article by V. Shulhin: "Our youth should know present day reality. Not an archaic history, not an archaic natural science, not an archaic equipment and not an archaic teacher. No, we need a teacher and a pupil with knowledge of the modern age". ${ }^{4}$

Consequently, there was no question of national, patriotic education in the context of the official ideology (philosophy) of internationalism. The state itself lost its previous significance. After all, according to Nadezhda Krupskaya "The Proletariat seizes power not to put labour into a privileged position, but in order to destroy all class domination, to destroy every state". ${ }^{45}$

Nevertheless, the party was in dire need of increasing the level of people's confidence and self-legitimisation in the eyes of the masses. In addition, the ongoing socialist experiment and economic policy of the authorities required considerable activity and interest, or at least loyalty from the citizens. Reasoning from the typical Bolshevik belief that "there are no such forms of science and art that would not be connected with the great ideas of communism," 46 the party leaders resolutely began to transform school into "a tool for the communist transformation of society"

The Bolsheviks openly, both in official documents and in the press, vested educational institutions with political and propaganda functions. Each teacher had to be a representative not only of general, but also of communist education. At the same time, the teacher reported not only to his authorities but to local party organisations as well. ${ }^{48}$

Thus, Bolsheviks, like their predecessors, intended to use school to create citizens loyal to their policies. However, since the old methods of personality moulding contradicted communist ideology it was necessary to find new methods. Labour had to become the main method of forming a new personality which would meet the ideals of party theorists and the needs of state building.

Lenin was convinced that "only by working together with peasants and factory workers is it possible to become a real communist." ${ }_{49}$ In his speech at the First All-Russian Educational Congress, Lunacharsky noted: "We consider labour to be an educational method because we realise, that only through collective labour can we develop a set of character traits necessary for a person to be strong and valuable... We will preserve such

${ }^{44}$ Shulhin V., About the purposes of school [in Russian], "Na putiakh k novoi shkole", 1923, no. 2(5), p. $15-16$.

${ }^{45}$ Krupskaya N., On the Question of the purposes of school [in Russian], "Na putiakh k novoi shkole", 1923, no. 2(5), p. 17.

${ }^{46}$ Directives of the All-Union Communist Party (bolsheviks) concerning education [in Russian], Moscow-Leningrad 1931, p. 25.

47 Ibidem, p. 11.

48 The Communist Party of the Soviet Union in resolutions and decisions of congresses, conferences and plenums of the Central Committee (1898-1986): in 15 v. [in Russian], Moscow 1983, vol. 2, p. 112.

${ }^{49}$ Lenin V., Complete Collection of Works: in 55 v. [in Russian], Moscow 1974, vol. 41, p. 317. 
quality of this labour that would allow the transformation of a small man into a big worker of socialist society". ${ }^{50}$

This opinion was supported by most Soviet pedagogues and theorists. They believed that "collective labour is the best way to educate the public". ${ }^{51}$ Thus, the process of labour itself had to replace religious and patriotic education as the main methods of forming a conscious and responsible citizen of a state.

The objective of the labour school was to educate a useful member of society - cheerful, healthy and hardworking, instilled with social instincts, possessing organisational skills, able to understand current events - a steadfast fighter for the ideals of the working class, a skilled builder of a communist society. ${ }^{52}$

However, the question of how to implement such ambitious and highly idealistic plans remained open, having caused many discussions on the pages of the pedagogical press throughout the 1920s.

A considerable part of communist teachers took the idea of the labour school literally, and focussed on the questions of hygiene, health, physical development, attaining such skills and knowledge necessary to work in a factory or in agriculture.

One of the supporters of this approach was the Deputy People's Commissar of Education of the Ukrainian SSR Jan Petrovich Ryappo. In his article "The problem of raising and educating children in the Soviet State," he put forward his slogan of proletarian education: "Everything - in consequence of production and everything - for the sake of production". 53

Another theorist of education, Pavel Blonsky, was of the same opinion. Paying considerable attention to the physical health of a child, in one of his articles, he regards a child's body as a physiological mechanism, where "like in any other good mechanism, strength and efficiency should be the main qualities". ${ }^{54}$ Continuing his thought, the author concluded that primary school should teach a child to protect himself from various diseases and to strive towards cleanliness and fresh air. ${ }^{55}$

Under the influence of such ideas, a rather radical revision of educational content began, which had to take a clearly pragmatic direction. There were appeals "to stop as soon as possible the outdated division into subjects, and to approach the mastering of labour skills and associated knowledge by way of concentric study of all aspects of production; which should be considered a knot, tying together all the threads of nature and society". ${ }^{56}$

\footnotetext{
${ }^{50}$ Lunacharsky A., On raising and educating children [in Russian], Moscow 1976, p. 29.

51 Gordon G.. New School [in Russian], "Na putiakh k novoi shkole", 1922, no. 1, p. 14.

52 Theses on Self-Governing (GUS) [in Russian], "Na putiakh k novoi shkole", 1923, no. 2(5), p. 6.

${ }_{53}$ Ryappo I., A problem of raising and educating children in the Soviet state [in Russian], "Put Prosveshcheniia", 1922, no. 4: 5 .

${ }^{54}$ Blonsky P., Pedagogical tasks of elementary school [in Russian], "Na putiakh k novoi shkole", 1922, no. 1 , p. 36 .

55 Ibidem, p. 37.

${ }^{56}$ Directives of the All-Union Communist Party (Bolsheviks) concerning education, p. 348.
} 
Moreover, those ideas came foremost from official authorities. Thus, at First Party Conference on people's education, held in December 1920 - January 1921, this principle was applied even to high school. The Bolsheviks considered it necessary to divide in principal two tasks: the training of a specialist worker and the training of a scientific researcher. ${ }^{57}$

Naturally, the circulation of such ideas in the press led to their considerable simplification. One of the Marxist teachers made an interesting statement, waiting, as per her quote, for a time, "when the reorganisation of science will take place and, to start with, it will be divided into two parts: 1) everything necessary for a civilised proletarian and 2) everything to satisfy a free, inquiring and curious mind". 58

However, an idea which in theory seemed rather simple and clear, in practice proved to be a monumental task for the vast majority of teachers. They did not know and could not know all the specifics of any given industrial process, since to gain the proper skills and knowledge it was necessary to master several production specialties at once, while, as mentioned above, a significant number of teachers had not even properly mastered their own profession.

The direct cooperation with production, which party theorists emphasised, also couldn't produce the necessary results, since during the first years of Soviet power the economy was in a really bad condition. The lack of qualified personnel could be seen in all spheres of the economy. Amidst economic collapse, factory managers were too busy with current manufacturing and staff problems to organise education and raising of youth. Moreover, they did not have any qualifications or methodological instructions for such activities, as well as there was no desire to spend time and energy on it.

The experience of one of the academic establishments is an example: "The attempt of Mykhailivsk technical college to send its students (from 4th year) on one month working practice to a state farm was not supported by the local land administration and the authorities noted the fact that there was nothing to learn there, since the state farms are badly managed". ${ }^{59}$ Therefore, when even the technical college was unable to organise such cooperation, what could be said of a regular school with much younger pupils, with whom there are more problems and a lot less benefits for production.

However, there was another, different, large group of teachers who considered the concept of the "labour school" to have a wider meaning. They took "work" to mean not only physical labour, but also mental work as well. They considered school reforms to be not so much a change in content as in the methods of the educational process. It was necessary to find an alternative to lectures during which students act as passive listeners and their task is limited to memorising the necessary amount of information. New methods, requiring students' activity, their direct participation in school life, were suggested

\footnotetext{
57 Directives of the All-Union Communist Party (Bolsheviks) concerning education, p. 353.

58 From the Letter of School Instructor [in Russian], "Na putiakh k novoi shkole", 1922, no. 2, p. 78.

59 Review of the Mykhailivsk Pedagogical Technical School of Krupskaya's Article [in Russian], "Na putiakh k novoi shkole", 1923, no. 7-8, p. 245.
} 
instead. That entails independent work on a certain topic, working with resources, working in groups, speeches, discussions, self-governance etc.

The professional views of these teachers evolved under the influence of progressive western pedagogical thought. The ideas of John Dewey's "labour training" were very popular, according to which the main task of the teacher is to identify the personal interests and needs of each student, to advise and stimulate him in the process of labour. The concept of "school of action" by German scientist Augustus William Lay also created great public interest. In addition, in 1920 the so-called "Dalton Plan", "the theory of free education", and "the theory of school extinction" were very often discussed in the pedagogical press.

Teachers that were more progressive considered the principle of activity and initiative of students to be the basis of the new school. One such teacher - Gabriel Gordon, even suggested replacing the term "labour school" with the term "action school". The author hoped that in this way, "the old prejudice associated with the notion of labour as predominantly physical" would be avoided". ${ }^{60}$

Progressive Marxist teachers interpreted the concept of "labour school" differently, and referred to mostly theoretical questions. Without going into detail, it should be pointed out that the central idea of this school, as the name implies, was labour that was simultaneously "a form of social interaction, a source of real knowledge, a method of learning, the subject of study, the basis of moral education, and finally, linguistic expression". ${ }^{61}$

However, the question of how to implement such a general idea in teaching practice in the conditions of the realities of Soviet Russia remained open. The All-Russian Congress of Left-Wing teachers, in its resolution, demanded "with all severity" the immediate publication of practical manuals, guidelines for teachers with a simple and clear description of ideas and methods of the labour school. ${ }^{62}$

Still, instead of simple and clear instructions, since 1919, the teachers received from the People's Commissariat of Education only "approximate" optional curricula on individual subjects. ${ }^{63}$ These curricula gave only a general outline of what a schoolteacher should do. The teacher himself had to fill them with more specific content based on local material. The curricula were received extremely coldly, even by the very few communist teachers. One of them writes: "I consider the People's Commissariat of Education drawing up curricula to be a waste of time, not only because no one uses them due to their incompatibility with modern conditions of the schools, but also because they are essentially incorrect". ${ }^{64}$

\footnotetext{
${ }^{60}$ Gordon G,.New School [in Russian], "Na putiakh k novoi shkole”, 1922, no. 1, p. 5.

${ }^{61}$ Tumim, Thoughts on Labour School, p. 136.

${ }^{62}$ Resolution of the Congress of Teacher-Internationalists. General Resolution [in Russian], "Narodnoe prosveshchenie", 1918, no. 4-5, p. 71.

${ }^{63}$ Krupskaya N., On the Question of Curricula, p. 3.

${ }^{64}$ From the Letter of School Instructor, p. 78.
} 
The party elite, engaged in various kinds of theorising and in drafting curricula, was completely cut off from the local teachers. In 1921 the editorial office of "Rabotnik Prosveshcheniia" - the publishing body of the All-Russian Union of Teachers - openly admitted this " ... the centre is completely cut off from the regions; one province from the other. We do not know, after all, what is going on in the midst of our family of teachers". ${ }^{65}$ Therefore, it is not surprising that even several years later practicing teachers still criticised the curricula, because they "have an academic manner and have features of the 'armchair' creativity". ${ }^{66}$

In practice, it turned out that the teacher himself had to organise all school affairs, starting from an independent search of the necessary forms and methods of training and ending with material procurement. Of course, only a few enthusiasts managed to independently build a new model school. Thus, describing their (quite successful) experience of organising school affairs in remote districts, the teachers remember how they started: "No guidelines, no reliable milestones were received from the centre. PDPE (the Provincial Department of Public Education - S.S.) was frank, stating 'We do not know - search, attempt by yourself and if we can, we will help" ${ }^{67}$

Under those conditions, a teacher with no experience and often without adequate education organised a "labour school" which was very far from the perfect model originally intended by the methodologists of the People's Commissariat for Education. There were frequent cases when sweeping the floor, pouring sewage, washing windows and other attributes of school "self-service" were considered as labour processes. ${ }^{68}$ There were cases where at school children were learning hard, for example, drama, painting, singing, model building, but did not learn to read or write; or were engaged in assemblies all day, and did not learn even four basic rules of arithmetic at school. ${ }^{69}$

Therefore, one can understand the sceptical attitude, especially common among the old teachers, to the "labour processes" at school, which "on the one hand, are the results of purely 'armchair' reflections of school 'reformers', on the other hand, lead to the fact that labour itself is actually abused, dishonoured, so to speak, in the process, and as a result, in the technique and the pedagogy". ${ }^{70}$

Consequently, the labour method in school did not contribute to the development of a new type of person, as the Bolshevik theoreticians expected. Teacher and academic A. Pinkevich in one of the issues of the "Prosveshchenie" journal wrote about the danger of the opposite effect of imposing labour at school as a basic teaching method: "due to

${ }^{65}$ To Education Workers [in Russian], "Rabotnik prosveshcheniia", 1921, no. 2-3, p. 3.

${ }^{66}$ Kudriavtsev A., History of Culture at the II Degree [in Russian], "Prosveshchenie", 1924, no. 4, p. 186.

${ }^{67}$ Veselov M., The Results of 3 Years Experience at School of the 2nd Degree (1918-1921) [in Russian], "Na putiakh k novoi shkole", 1923, no. 7-8, p. 137.

68 Gardon G., New School, p. 9.

${ }^{69}$ Krupskaya N., To the Questions of Programs, p. 3.

70 Arzhanov S., Around School Being Built, p. 152. 
incompetent repetition of the same words, an annoying and unconvincing imposition of the same thought, the student will hate both labour and socialism". ${ }^{71}$

\section{Turning to the teacher}

In general, this situation generally continued throughout the entire Civil War period, when the state functioned in the "military communism" mode and operated a failed system of centralised financing for public education. Despite the fact that since 1921 there had been greater interest in teachers' problems and situation, the crisis in school education was lengthened due to the famine of 1921-1922.

In time, the top of the Bolshevik Party began to understand that the main prerequisite for the success of educational policy was not the development of the theory of a new school, not the expansion of the school network and not the re-training of teachers on short-term courses, but raising the level of financial support for teachers. At the $10^{\text {th }}$ All-Russian Congress of Soviets, Anatoly Lunacharsky, the People's Commissar of Education, for the first time made a speech which was entirely devoted to the economic condition of schools and teachers. ${ }^{72}$

The question of material support in the field of public education was for the first time raised at the highest level, and, in particular, the People's Commissar paid a lot of attention to the catastrophic situation of the people's teacher: "Among our teachers there are horrendous facts of begging, premature death, colossal diseases, prostitution, etc." The picture of our teachers' lives at this time is mind-blowing, and no one should be surprised that these teachers have fled as far as possible". ${ }^{73}$ Lunacharsky highlighted the injustice of the principles of remuneration for the teacher, because it was their work that was ranked lowest among all professions. The teacher received a much lower salary than the workers of other spheres - communal workers, textile workers, builders and the like. On average, a teacher received a salary that was only $12 \%$ of the living minimum. ${ }^{74}$

Further, the speaker put forward a number of ideas for where to find additional funds to finance basic school needs, among which were those contradicting the official ideology and party principles: introduction of tuition fees for certain categories of the population, introduction of a special tax for the maintenance of educational establishments etc.

In addition to financial issues, Lunacharsky considered it necessary to change the attitude of party members towards teachers. He called on the participants of the congress to pass on to their colleagues and subordinates that "The teacher is not a pariah, but a hero, for this is the person who stayed in an unheated school and starved." In the con-

71 Pinkevich A., To reform of the second degree of labor school [in Russian], "Prosveshchenie", 1923, no. 3, p. 129.

72 The tenth All-Russian Congress of Soviets of Workers, Peasants, Red Army and Cossack Deputies (December 23-27, 1922): Transcript with addenda [in Russian], Moscow 1923, p. 73-90.

73 The tenth All-Russian Congress of Soviets..., p. 77.

${ }^{74}$ Ibidem, p. 78. 
clusion to his speech, Lunacharsky once again motivated his party colleagues to finally pay attention to the problems of education, and asked the audience a rhetorical question: "Will there be further agony or will recovery begin?". ${ }^{75}$

However, Lenin's article titled "Pages from a diary", published in "Pravda" on January 4, 1923 is considered to be the beginning of the "turn" in the Bolshevik policy towards teachers. The author raises the problem of the cultural and educational development of the republic, urging the reduction of expenses of other departments with the aim of allocating the released funds to the needs of the People's Commissariat for Education: "Do not be stingy with the increase of bread rations for the teachers in a year such as this, when we are relatively well supplied". Further, Lenin outlines the main idea of the article: "The people's teacher should be raised to such a height that he has never reached and cannot reach in bourgeois society. ... We must achieve this through working hard and systematically on his spiritual improvement and his well-rounded training for this really high rank and, most importantly, the main and most important thing - on improving his financial position". ${ }^{76}$

Lenin's article became an important signal for ordinary party members. It can be considered an official response to those critical issues raised by the People's Commissar for Education at the Congress. A positive improvement in the party's attitude towards teachers began notably after this article and was expressed both in the press, and in the decisions of congresses and government.

Equally important, the press raised the question of the prejudiced attitude within the party towards teachers. The subjective attitude of local authorities to the needs of public education was noted in one of these articles. This attitude can be described, if not as indifference then as a lack of proper attention. Though such an attitude was partially justified by poverty and the priority of economic problems, the idea of the "untimely" needs of public education and the postponement of this issue was sharply condemned. ${ }^{77}$

In another article, the author writes about how "in the old fashion way and following tradition" in the press and in private conversation "the teacher continues to be laughed at: he is antiquated, and of priestly descend, and a counter-revolutionary, etc., etc." The author does not rule out the existence of such individuals, but is opposed to pinning such labels on all teachers. In his opinion, this complicates the "organic transformation of the teacher". 78

One of the instructors engaged in political work among teachers believed that it was important to make for them a "window into Soviet power and communism." He considered the identification of friendly and suitable individuals for the Bolsheviks to be the purpose of these courses.

\footnotetext{
75 Ibidem, p. 89.

${ }^{76}$ Lenin V., Complete Collection of Works: in 55 v. [in Russian], Moscow 1968, vol. 45, p. 365-366.

77 On the new front [in Russian], "Rabotnik prosveshcheniia", 1923, no. 3, p 1.

${ }^{78}$ About some shift [in Russian], "Rabotnik prosveshcheniia", 1923, no. 9, p 29.
} 
The Bolsheviks themselves realised that they "need at all costs to acquire friends and allies among teachers, who would, not out of fear, but out of conscience, become earnest and capable agents carrying their goals and objectives to the younger generation". ${ }^{79}$

The increase of attention towards teachers by the authorities was the first step towards establishing cooperation between the authorities and the schools, and the development of a new educational system.

\section{Conclusion}

The education system is one of the most commonly used and most influential tools of social control used by the government. The task of promoting the existing state system directly affects the professional activity of teachers and requires them to be loyal to the system. The situation that developed in the educational system of Russia in 1917-1923 is a rather interesting illustration of the problems of the relationship between teachers and authorities.

The October coup started a new, rather ambiguous period in the history of Russian education. During the first years of Soviet power in this sphere, innovative pedagogical experiments and the total decline of the school system due to economic collapse, civil war antagonisms and state policy radicalism were combined.

Remarkably, Pavel Blonsky, who as a member of the Scientific and Pedagogical Section of the State Academic Council, had within a few years already taken direct part in the creation of Soviet school curricula, immediately after the coup wrote:

"Is it necessary to create new school right now? No, it is not necessary, it is even harmful, more than that, it is destructive... If the old school would be destroyed, and a weak, not very influential authority would order the creation of a new school based on the old school plans, won't there be a passive local resistance and teacher sabotage, more dangerous to children? To create a new school right now means absolute failure". ${ }^{80}$

As we can see, the words of the famous pedagogue became prophetic. The conflict between the Bolsheviks and teachers, caused by ideological differences and political upheavals, resulted in the authorities' neglect of educational needs (especially at the local level). The profession of teacher became one of the least prestigious, resulting in a significant drop in numbers and decrease of teachers' professional competency.

The authorities, at the same time, continued to communicate with teachers in an imperious manner, expecting from them incredible enthusiasm in the development of the new school. Bolshevik theorists, while developing the principals of the so-called "labour school", were alienated from ordinary teachers, which often led to utopian and idealistic observations in pedagogical press. These observations not only did not help, but confused the teachers even more. Consequently, Lunacharsky at the end of 1920s assessed the state p. 1.

79 Dayan G., About political work among teachers [in Russian], "Rabotnik prosveshcheniia", 1923, no. 20,

${ }^{80}$ Blonsky P., Selected pedagogical works [in Russian], Moscow 1961, p. 146. 
of affairs in education as follows: "Five years have already passed since there were perfect plans and actual ruin in this field". ${ }^{81}$

After the end of the Civil war and the famine of 1921-1922, in 1923 the authorities at last paid attention to the state of affairs in the public education sector. However, it was just the beginning of work on solving the problems described above, which to some extent accompanied the Soviet education system throughout all the 1920s.

Thus, the period from 1917 to 1923 was a period of stagnation for the entire educational system. The Bolsheviks' policy not only did not help to overcome these the negative factors that influenced the educational system, but also greatly increased the effect of those factors, which led to apathy even from Marxist teachers. The consequences of the first years of school reform were successfully summed up by one of the most knowledgeable teachers of her time, and a supporter of the "labour school", Raisa Lemberg: "The school could not simultaneously adapt to the needs of childhood and adolescence, the demands of "life "and the demands of higher education. None of the authorities "guiding" school work were satisfied with its results or even with its plans". ${ }^{2}$

Naturally, the result of the reforms would have been much better, and their implementation would have been less painful if they had occurred in an atmosphere of mutual understanding and active cooperation between authorities and teachers. However, in the political and social conditions that developed in 1917-1923 this was practically impossible.

The Bolshevik approach to reforming the education system can be seen as an example of a radical way of building the concept of a new education. The ambitious, revolutionary and largely Utopian goals that the Soviet authorities placed on the new school were too detached from the traditionalist attitudes of most teachers and involved a decisive rejection of everything laid down by the previous system. This determined the educational policy of the authorities, which, although it had positive features, as a result of a number of mistakes and unfavourable circumstances, had a generally detrimental effect on the quality of education.

\section{Bibliography}

About some shift [in Russian], "Rabotnik prosveshcheniia", 1923, no. 9

Alferov S., The Needs of the Don People's School [in Russian], "Pedagogicheskaia mysl". The journal issued by the Department of People's Enlightenment of the Don Great Army, 1918, no. 2

Blonsky P., Pedagogical tasks of elementary school [in Russian], "Na putiakh k novoi shkole", 1922, no. 1

Blonsky P., Selected pedagogical works [in Russian], Moscow 1961

Bushchyk L., Essay of School History Education Development in the USSR [in Russian], Moscow 1961

\footnotetext{
81 The tenth All-Russian Congress of Soviets..., p. 80.

${ }^{82}$ Lemberg R., To reform of the secondary school, [in Russian], "Prosveshchenie", 1923, no. 3, p. 6.
} 
Charter of Union of Teacher-Internationalists [in Russian], Narodnoe prosveshchenie, 1918, no. $1-2$

Dayan G., About political work among teachers [in Russian], "Rabotnik prosveshcheniia", 1923, no. 20

Decrees of Soviet Power [in Russian], Moscow 1974

Department of Secondary Schools [in Russian], Narodnoe prosveshchenie, 1918, no. 1-2

Directives of the All-Union Communist Party (bolsheviks) concerning education [in Russian], Moscow-Leningrad 1931

Essays on the History of School and Pedagogical Thought of the USSR. (1917-1941), ed. N. Kuzin, M. Kolmakova, Z. Ravkin [in Russian], Moscow 1980

Fitzpatrick S., The Commissariat of Enlightenment: Soviet Organization of Education and the Arts under Lunacharsky, October 1917-1921, Cambridge 2002

From the Letter of School Instructor [in Russian], "Na putiakh k novoi shkole", 1922, no. 2

Gordon G.. New School [in Russian], "Na putiakh k novoi shkole", 1922, no. 1

Higher School of the Ukrainian SSR for 50 years, v. 1-2, ed. V. PIPOV, [in Ukrainian], Kyiv 1967

Holmes L.E., The Kremlin and the Schoolhouse: Reforming Education in Soviet Russia, 19171931, Bloomington 1991

Kalashnikov A., On the Preparation of Educators [in Russian], "Rabotnik prosveshcheniia", 1921, no. 7

Kapterov P., L. N. Tolstoy and the modern school conversion [in Russian], "Pedagogicheskaia mysl", 1919, no. 1:2.

Kozelev B., Our Greetings to the Teachers and Education Employees of All Countries - the Delegates of the 1st World Congress of Trade Unions [in Russian], "Rabotnik prosveshcheniia", 1921, no. 7

Krupskaya N., To the Questions of Programs [in Russian], "Na putiakh k novoi shkole", 1922, no. 2: 3 .

Krupskaya N., On the Question of the purposes of school [in Russian], "Na putiakh k novoi shkole", 1923, no. 2(5)

Krupskaya N., Pedagogical Works [in Russian], Moscow 1957

Kudriavtsev A., History of Culture at the II Degree [in Russian], "Prosveshchenie", 1924, no. 4

Lemberg R., To reform of the secondary school, [in Russian], "Prosveshchenie", 1923, no. 3

Lenin V., Complete Collection of Works: in 55 v. [in Russian], Moscow 1969-1974

Lunacharsky A., About the Upbringing and Education [in Russian], Moscow 1976

Lunacharsky A., Memories and Impressions [in Russian], Moscow 1968

Lunacharsky A., On raising and educating children [in Russian], Moscow 1976

Lunacharsky A., On the abolition of marks [in Russian], "Narodnoe prosveshchenie", 1918, no. 4-5

Mankivska T., The Policy of Soviet Power Concerning Teachers in 1917-1921 (based on data from Slobozhanskyi Region) [in Ukrainian], “Zbirnyk naukovykh prats' Kharkivs'koho natsional'noho pedahohichnoho universytetu imeni H. S. Skovorody", 2012, no. 44

Marx K., Engels F., Manifesto of the Communist party [in Russian], Moscow 1974

Marx K., Engels F., Works [in Russian], Moscow 1960

On the new front [in Russian], "Rabotnik prosveshcheniia", 1923, no. 3

Pinkevich A., About the necessity of Marxist pedagogy [in Russian], "Na putiakh k novoi shkole", 1923, no. 1(4)

Pinkevich A., To reform of the second degree of labor school [in Russian], "Prosveshchenie", 1923, no. 3

Pokrovsky M., Selected Works [in Russian], Moscow 1967

Radchenko A., Training of School Employees at the Local Level [in Russian], "Na putiakh k novoi shkole", 1922, no. 2 
Resolution of the Congress of Teacher-Internationalists. General Resolution [in Russian], "Narodnoe prosveshchenie", 1918, no. 4-5

Review of the Mykhailivsk Pedagogical Technical School of Krupskaya's Article [in Russian], "Na putiakh k novoi shkole", 1923, no. 7-8

Review of the Mykhailivsk Pedagogical Technical School of Krupskaya's Article [in Russian], "Na putiakh k novoi shkole", 1923, no. 7-8

Ryappo I., A problem of raising and educating children in the Soviet state [in Russian], "Put Prosveshcheniia", 1922, no. 4

Second degree of the Soviet labour school. Organisation. Contents. Methods [in Russian], Moscow 1929

Sergeyev I., Financial Situation of 'People's Teacher' in Soviet Russia in 1917-1921 [in Russian], "Visnyk Kharkivs'koho natsional'noho universytetu im. V.N. Karazina", 2007, no. 39, pp. 185-197

Shulgin V., On the Question of Work with Teachers [in Russian], "Na putiakh k novoi shkole", 1922, no. 2

Shulhin V., About the purposes of school [in Russian], "Na putiakh k novoi shkole", 1923, no. 2(5)

Solodub P., Revolution and People's Teacher [in Ukrainian], "Radianska osvita", 1925, no. 1

The Communist Party of the Soviet Union in resolutions and decisions of congresses, conferences and plenums of the Central Committee (1898-1986): in 15 v. [in Russian], Moscow 1983, vol. 2

The tenth All-Russian Congress of Soviets of Workers, Peasants, Red Army and Cossack Deputies (December 23-27, 1922): Transcript with addenda [in Russian], Moscow 1923

Theses on Self-Governing (GUS) [in Russian], "Na putiakh k novoi shkole", 1923, no. 2(5)

To Education Workers [in Russian], "Rabotnik prosveshcheniia", 1921, no. 2-3

Tumim G., Thoughts on Labor School [in Russian], "Prosveshchenie", 1923, no. 3

Veselov M., The Results of 3 Years Experience at School of the 2nd Degree (1918-1921) [in Russian], "Na putiakh k novoi shkole", 1923, no. 7-8

Vitukhnovskij G., Fight for Teachers in the First Months of Soviet Power [in Russian], "Sovetskaia Pedagogika", 1956, no. 11 